\title{
A comparison of nutritional status of primary school children in two settlements in the Polonnaruwa District
}

${ }^{*}$ R.R.M.L.R.Siyambalagoda', P.A.J.Perera ${ }^{2}$, A.R. Wickremasinghe ${ }^{3}$, N.P.Sumanaweera ${ }^{4}$

The Ceylon Journal of Medical Science 2003; 46: 2I-33

Abstract

This study was conducted to ässess and compare the nutritional status of primary school children of a new (Mahaweli System "B") and an old settlement (Parakrama Samudraya)area in the Polonnaruwa district. A total of 941 and 719 primary school children from the new and old settlements, respectively, were studied. Heights and weights of primary school children were measured using standard techniques. Finger prick blood samples were obtained to measure haemoglobin concentrations using "ERMA AE-11N"photoelectric colorimeter. Weight-for-age, heightfor-age and weight-for-height $\mathrm{z}$-scores were calculated using EPIINFO. The nutritional status of the primary school children of the new settlement were poorer than those in the old settlement in all three anthropometric indicators, namely stunting, wasting and underweight. The prevalence of stunting among children from the new settlement $(36.2 \%$ and $31.2 \%$ in males and females respectively) was significantly higher than those of children in the old settlement $(29.0 \%$ and $28.6 \%$ in males and females respectively). The prevalences of wasting among children from the new settlement $(51.8 \%$ and $48.2 \%$ in males and females respectively) were significantly higher than that of children in the old settlement ( $27.3 \%$ and $23.2 \%$ in males and females respectively). The prevalence of underweight was $65.4 \%$ and $62.4 \%$ in the new settlement and $47.2 \%$ and $38.3 \%$ in the old settlement, in male and female children, respectively. More than $85 \%$ of the children were anaemic with the prevalence being significantly higher among children from the new settlement $(91.5 \%)$ as compared to those from the old settlement $(72.3 \%)$.
Key words - Agricultural settlements, primary school children, protein energy malnutrition, anaemia

\section{Introduction}

Polonnaruwa district is situated in North-Central Sri Lanka. The estimated mid-year population of the district in 1997 was 367,000 comprising mainly rural areas except for two small townships. The district has old agricultural settlements commenced in the early 1940's and new ones started in the early 1980's. The old settlements have well established colonies with facilities and services like transport, education and health. In the new settlements these services, mainly health, were poorly established during and before the study period. The new settlements also faced the security threat caused by the civil unrest in the country.

Very few studies assessing nutritional status have been carried out on primary school children as compared to pre-school children whose nutritional status is regularly assessed by national surveys (1). According to a national survey carried out in Sri Lanka in 1993 the prevalence of stunting was $18.9 \%$ and $22.7 \%$ among male and female children under 36 months of age. The prevalence of wasting was $13.8 \%$ and $14 \%$, and of underweight was $30.7 \%$ and $34.6 \%$ among male and female children in the same age group (1). Based on epidemiological criteria, Sri Lankan children will be categorised as "medium", on stunting and "very high" on both wasting and underweight $(2,3)$.

Anaemia is considered an important public health problem among high risk groups such as children and pregnant mothers in Sri Lanka.

' Former Deputy Provincial Director of Health Services, North Central Province and current Deputy Director, Anti-Malaria Campaign Headquarters, Sri Lanka.

${ }^{2}$ Department of Biochemistry, Faculty of Medicine, University of Peradeniya

${ }^{3}$ Department of Community Medicine \& Family Medicine, Faculty of Medical Sciences, University of Sri Jayewardenepura

${ }^{4}$ Department of Health, Sri Lanka

*Corresponding author 
It is widely accepted that household socio-economic characteristics with biological and behavioural variables are important determinants of malnutrition $(4,5)$. In the past, it was widely believed that socio-economic constraints and undernutrition are more prevalent among primary school children of the new settlements as compared to those of the old settlements. Hence, this study was carried out with the objective of determining whether in fact this was so.

\section{Methods}

This cross sectional study was carried out from January to August 1993. All Public Health Inspector $(\mathrm{PHI})$ ranges in the settlements were included except Welikanda and Senanapitiya in the new settlement due to security reasons. The estimated number of primary school children in the new and old settlements were 5000 and 10,300 , respectively. There were 47 and 45 schools in the new and old settlements, respectively. There was no primary section in one school of the old settlement.

One $\mathrm{PHI}$ range from each settlement was selected randomly and all primary school children were studied. A sample of 800 primary school children was required from each settlement to detect a difference of $5 \%$ with an alpha error of $5 \%$ and a power of $90 \%$ (6). PHI ranges "Dimbulagala" and "Parakrama Samudraya" were selected from the new and old settlements respectively. A total of 941 primary school children attending 11 schools in Dimbulagala and 719 children attending 4 schools in Parakrama Samudraya selected for the study.

Children were enrolled in the study after obtaining informed consent from parents or guardians. Children who were absent on the day of the survey, who did not cooperate or whose parents or guardians did not give consent were exuded from the study. Data on age, sex and the dates of birth were extracted from school registers. All the children in these schools had birth certificates and the class teachers entered the dates of birth in the registers.

The weights of the children were measured to the nearest 100 grams using a "Detecto" adult weighing scale as recommended by the WHO(7).
The weighing scale was calibrated twice daily and checked against standard weights of 10 and $30 \mathrm{~kg}$ provided by the district price control unit. Two trained investigators recorded all weights. Wherever there was a difference between the recordings of two investigators the average weight was recorded. Every $10^{\text {th }}$ measurement was doublechecked by both investigators. The heights were measured to the nearest $0.1 \mathrm{~cm}$ with a "Microtoise" portable height-measuring gauge.

Blood samples for haemoglobin estimation were collected by finger prick using sterile, disposable lancets. The samples were transported to the laboratory at the Base Hospital, Polonnaruwa. Haemoglobin concentrations were estimated using an "Erma AE-11-N" photoelectric colorimeter. A haemoglobin concentration less than $12.0 \mathrm{~g} / \mathrm{dL}$ was taken as the cutoff value to define anaemia.

Data were checked for accuracy and consistency prior to computer entry in EPIINFO (version 5) software package. The antropometric status of children was assessed using Z-scores of weightfor-age, height-for-age and weight-for-height calculated as the deviation from the reference median as recommended by the WHO using the EPINUT subroutine of EPIINFO (8). A Z-score of $-2 \mathrm{SD}$ was used as the cutoff value to define a state of undernutrition $(9,10)$. Weight-for-height for males were calculated only if they were less than $145 \mathrm{cms}$ in height, and for females only if they were less than 120 months and $135 \mathrm{cms}$ in height. Weight-for-age and height-for-age were calculated for all children under 18 years of age (8). The WHO recommended subtraction of 2.3 percent was not used in the estimation of prevalence of undernutrition as the study was a comparative one (11).

\section{Results}

94 I children from Dimbulagala, (508 males), and 719 children from Parakrama Samudraya, (373 males), were studied. In the old settlement there were no children below 6 years.

The distribution of height-for-age and weight-forheight with the reference distribution is shown in 
Figures 1 and 2. Although height-for-age was similar and below the reference median in children of the 2 settlements, weight-for-height, a measure of acute on chronic malnutrition, was less in children from the new settlement.

The mean weights of male and female children are given in Table $\mathrm{I}$. Weights of both male and female children of different age groups from the new settlement were significantly less than those of the corresponding age-sex group of children from the old settlement, except among male children between 108 to 119.9 months.

The mean heights of male and female children are given in Table 2. In general, the heights of both male and female children of the new settlement were less than those of children of the old settlement. The prevalence of stunting among male and female children is given in Table 3. Approximately $30 \%$ of children were stunted in both settlements with the prevalence being higher among the children in the new settlement as compared to the old settlement. Although the prevalence of stunting was higher among children from the new settlement in the lower age groups, the prevalence among older children was higher for those of the old settlement.

The prevalence of wasting for both male and female children was significantly less among children of the old settlement for all age groups considered (Table 4). The comparisons were made only for children who had a reference population. The prevalence of underweight among children in the new settlement was significantly higher than their counterparts in the old settlement (Table 5). Among all children, more than $50 \%$ were underweight.

There were no statistically significant differences in anthropometric indices (stunting, wasting and underweight) between males and females in either the new and old settlements except in underweight among children in the old settlement $\left(c^{2}=7.99 ; p=0.0047\right.$ ).

Haemoglobin concentrations were measured in 908 students from the new settlement and 369 students from the old settlement. The haemoglobin concentrations of children in the new settle ment ranged from $6.74 \mathrm{~g} / \mathrm{dL}$ to $15.04 \mathrm{~g} / \mathrm{dL}$ while those of the old settlement ranged from $6.24 \mathrm{~g} / \mathrm{dL}$ to $15.5 \mathrm{~g} / \mathrm{dL}$ (Table 6). Overall the prevalence of anaemia was over $85 \%$. The prevalence of anaemia was significantly greater among both male and female children in the new settlement as compared to those of the old settlement. In the new settlement, $92.8 \%$ of male children and $90.1 \%$ of female children were anaemic as compared to $70.7 \%$ of male and $74.4 \%$ of female children in the old settlement.

\section{Discussion}

The anthropometric status of children of both settlements indicates the comparatively poor past and present nutritional status of the inhabitants compared to the reference population. In the new settlement, malnutrition amongst primary school children is more marked as compared to children of the old settlement. If the nutritional status of primary school children is a reflection of overall socio-economic development, then the results of this study favour the original hypothesis of the investigators that the new settlement is worse off than the old settlement. The results of this study are indicative of a poorer state of health, nutrition, and social wellbeing of primary school children of the new settlement as compared to those of the old settlement.

There probably are a number of factors that may explain the poorer nutritional status of children in the new settlement among which provision of health services and other social welfare programmes may be of paramount importance. The new settlement was started in the early 1980's while the old settlement was established in the 1930's. The old settlement is located in the Thamankaduwa $\mathrm{MOH}$ area, a comparatively urban area with better health and other facilities. All public health staff positions were filled and supervisory mechanisms were better operated in this area at least in the last decade. The largest curative care institution is also located in this area. Lankapura is also an old settlement, but in contrast to Thamankaduwa, it is underdeveloped health wise. Other facilities like transport etc. are also poorer as compared to those in Thamankaduwa. Dimbulagala is a new Mahaweli settlement started in the 1980's and is still devel- 
-oping. There are still a large number of staff vacancies, particularly of Public Health Midwives who play the most important role at the grass roots level.

The children of this study comprise the second gencration of the population in the area. During the early years of the settlements the inhabitants were provided with many incentives including dry rations, settlement allowance, etc. until they were formerly settled and cultivation work commenced. Almost all the settlers had arrived from rural areas of the country where the nutritional state is low (1). The results of this study reflect the need for more help to be given to such settlers.

The prevalence of stunting, an indicator of longterm nutritional status, of female primary school children in the new and old settlements, was not significantly different but in male children was marginally significant. In contrast, wasting between children of old and new settlements was significantly different in both sexes. This indicates the poorer level of present nutritional status among the children of the new settlement as compared to those of the old settlement. The prevalence of underweight was significantly higher among children of the new settlement. The poor and slow rate of development of the new settlement coupled with other factors such as the unsatisfactory security situation that prevailed in the area during the study would have contributed to the difference. The old settlement had well established irrigation, health, education, and other facilities and no security threat as compared to the new settlement which probably is a major reason for the better nutritional status of children of the old settlement as compared to the new one.

In this study it was observed that the prevalence of wasting ( $51.8 \%$ and $48.2 \%$, for males and females, respectively) in the new settlement was higher than the prevalence of stunting (36.2\% and $31.2 \%$ for males and females, respectively). Usually, in nutritional surveys, the prevalence of wasting is lower than the prevalence of stunting. This phenomenon demonstrates the degree of the present socio-economic strain on the nutritional status of primary school children of the new settlement. In the old settlement the prevalence of wasting was lower than that of stunting.
The prevalence of stunting among children of Polonnaruwa was approximately $32 \%$ in boys and $30 \%$ in girls. In a study of children of Talkote, a "purana" village near Sigiriya carried out in 1989, almost all children ( $100 \%$ of boys and $90 \%$ of girls) 5 to 14 years had a Body Mass Index(BMI) less than 18.5 (12). The BMI is an index of chronic dietary energy deficiency. Children in the present study appear to be better nourished than the children resident in the "purana" village.

In a study of school children from different locations of the Colombo District reflecting different socio-economic strata of the population, Wikramanayake and Amarasinghe reported that the BMI of affluent children is higher than that of less affluent children and are comparable to that of children of Chinese descent in Hong Kong but markedly different from those of affluent Indian girls in New Delhi and Irish and American populations (13). The differences in nutritional status seen among school children resident even within close proximity, as was seen in this study between children of the old and new settlements, is a reflection of the significant impact of many socioeconomic factors on nutrition.

The results of this study indicate that anaemia is a major public health problem among these children. The relatively better haemoglobin status coupled with the better anthropometric status among children of the old settlement as compared 10 children of the new settlement is a reflection of the poorer socio-economic status, in general, of the families of the new settlement. The most probable cause of the anaemia is iron deficiency which may be due to poor dietary intake as well as presence of concomitant helminth infections. At the time of the study, the prevalence of hookworm infestation among children of the new settlement was $13 \%$ as compared to no infestation amony children in the old settlement. The differences in the prevalence of anaemia between children of the 2 settlements may be due to differences in the prevalence of hookworm infection.

Another important finding of this study is the absence of a consistent difference between males and females in either of the two settlements with regard to anthropometric status and haemoglobin concentrations. 
The results of this study have far reaching implications. Firstly, the poor nutritional status of primary school children in rural communities needs to be addressed. Nutrition programmes should be designed and implemented specifically for these communities. In addition, adequate health care facilities should be provided. Secondly, the poorer nutritional status of primary school children of the new settlement as compared to those of the old settlement requires that these settler communities should be provided with adequate health care facilities and possibly other benefits such as food subsidies to mitigate effects of socio-economic factors that these communities may have to face. These facilities should be planned well in advance and implemented as soon as settlement is done. Not addressing these issues will only result in a failure of the entire settlement programme. In addition, as nutritional status has a significant impact on health and learning abilities in school, neglecting the nutritional status of these children will only result in a waste of investments made in the educational sector. Focused nutrition interventions and provision of adequate health care to this age group will not only be of benefit to the target population per se, but will have a ripple effect on other segments of society as well, such as pregnant mothers, preschool children and adults. This will be of benefit for the communities as a whole to be more economically productive.

\section{References}

1. Department of Census and Statistics. Sri Lanka Demographic and Health Survey, 1993. Ministry of Finance, Planning, Ethnic Affairs and National Integration, in collaboration with Ministry of Health; Highways and Social Services, Colombo, Sri Lanka, 1995.

2. Amarasinghe $\mathrm{S}$, Wickramanayake TW. Auxology of Sri Lankan children aged 5-18 years, height, weight and growth increments. Ceylon Journal of Medical Science 1989; 32: 59-84.

3. Victoria CG, Vaughon JP, Kirkwood BR, Martines JC, Barcelos LB. Risk factors for malnutrition in Brazilian children: The role of social and environmental variables. Bulletin of the World Health Organization 1986; $64: 299-309$.
4. Ricci JA, Becker S. Risk factors for wasting and stunting among children in Metro Cebu, Philippines. American Journal of Clinical Nutrition 1996; 63: 966-975.

5. Ramanujam $P$, Nestel P. Preliminary Report on the Fourth National Nutrition and Health Survey July-August, 1995. Ceylon Journal of Medical Science 1997; 40: 13-24.

6. Pearson JCG, Turton A. Statistical Methods in Environmental Health. Chapman and Hall, 1st Edition, 1993.

7. World Health Organization. Methods recommended for essential clinical, chemical and haematological tests for intermediate hospital laboratories. WHO/Lab/86.3, 1986.

8. World Health Organization. Measuring change in nutritional status - Guidelines for assessing the nutritional impact on supplementary feeding programmes for vulnerable groups. WHO, Geneva, 1983.

9. Keller W, Fillmore CM. Prevalence of protein energy malnutrition. World Health Statistical Quarterly 1983; 36: 129-167.

10. Gibson RS. Principles of Nutritional Assess ment. Oxford University Press, 1990.

11. World Health Organization. Report of a working group. Use and interpretation of anthropometric indicators of nutritional status. Bulletin of the World Health Organization 1986; 64: 929-941.

12. Chandrasekara MS, Wickramanayake ER. Body Mass Index of the inhabitants of a Purana village in Sri Lanka. Ceylon Journal of Medical Science 1992; 35: 53.

13. Wikramanayake TW, Amarasinghe $\mathrm{S}$. Auxology of Sri Lankan children aged 5-18 years: 2. Quetelet's Body Mass Index. Ceylon Journal of Medical Science 1990; 33: 1-14. 
Table 1. Weights of primary school children by age

\begin{tabular}{|c|c|c|c|c|c|c|c|}
\hline \multirow{2}{*}{$\begin{array}{l}\text { Age in } \\
\text { months }\end{array}$} & \multicolumn{3}{|c|}{ New Settlement } & \multicolumn{3}{|c|}{ Old Settlement } & \multirow[b]{2}{*}{ p value } \\
\hline & $\mathbf{N}$ & Mean & $\mathrm{SD}$ & $\mathbf{N}$ & Mean & SD & \\
\hline \multicolumn{8}{|l|}{ Males } \\
\hline $60-71.99$ & 45 & 15.06 & 2.13 & - & - & - & - \\
\hline $72-83.99$ & 94 & 15.89 & 1.97 & 27 & 17.16 & 2.23 & $<0.001$ \\
\hline 84-95.99 & 85 & 17.33 & 2.55 & 62 & 18.51 & 2.12 & $<0.050$ \\
\hline $96-107.99$ & 84 & 18.60 & 2.34 & 57 & 20.02 & 2.57 & $<0.001$ \\
\hline 108.119 .99 & 76 & 20.77 & 3.09 & 60 & 22.13 & 3.04 & NS \\
\hline $120-131.99$ & 70 & 21.64 & 2.57 & 69 & 20.13 & 3.06 & $<0.001$ \\
\hline$>=132$ & 54 & 24.42 & 3.35 & 98 & 26.54 & 3.16 & $<0.050$ \\
\hline \multicolumn{8}{|l|}{ Females } \\
\hline $60-71.99$ & 30 & 14.34 & 1.67 & - & - & - & - \\
\hline $72-83.99$ & 81 & 15.43 & 1.87 & 19 & 16.47 & 2.07 & $<0.005$ \\
\hline 84-95.99 & 59 & 17.60 & 4.09 & 51 & 18.53 & 2.16 & $<0.001$ \\
\hline $96-107.99$ & 93 & 17.92 & 2.44 & 67 & 20.06 & 2.53 & $<0.001$ \\
\hline $108-119.99$ & 67 & 20.33 & 4.28 & 57 & 22.19 & 3.51 & $<0.001$ \\
\hline $120-131.99$ & 54 & 21.99 & 2.70 & 86 & 24.63 & 3.68 & $<0.001$ \\
\hline$<=132$ & 49 & 23.97 & 3.86 & 66 & 28.57 & 5.60 & $<0.001$ \\
\hline
\end{tabular}

NS- Not significant, N-Number of children 
Table 2. Heights of primary school children by age

\begin{tabular}{cccccccc}
\hline \multirow{2}{*}{$\begin{array}{c}\text { Age in } \\
\text { months }\end{array}$} & \multicolumn{6}{c}{ New Settlement } & \multicolumn{3}{c}{ Old Settlement } \\
\cline { 2 - 8 } Males & & Mean & SD & N & Mean & SD & p value \\
\hline $60-71.99$ & 45 & 107.83 & 10.66 & - & - & - & \\
$72-83.99$ & 94 & 111.76 & 9.02 & 27 & 113.45 & 3.98 & $<0.001$ \\
$\mathbf{8 4 - 9 5 . 9 9}$ & 85 & 116.69 & 5.77 & 62 & 118.29 & 4.31 & $<0.001$ \\
$96-107.99$ & 84 & 120.86 & 5.47 & 57 & 121.63 & 5.68 & 40.025 \\
108.119 .99 & 76 & 126.79 & 6.48 & 60 & 126.27 & 5.00 & NS \\
$120-131.99$ & 70 & 129.78 & 5.42 & 69 & 128.73 & 4.75 & $<0.01$ \\
$>=132$ & 54 & 136.50 & 7.24 & 98 & 135.70 & 6.55 & NS \\
Females & & & & & & & \\
$\mathbf{6 0 - 7 1 . 9 9}$ & 30 & 108.87 & 7.53 & - & - & - & - \\
$72-83.99$ & 81 & 110.97 & 5.55 & 19 & 111.57 & 4.07 & NS \\
$\mathbf{8 4 - 9 5 . 9 9}$ & 59 & 117.03 & 5.48 & 51 & 116.85 & 5.73 & NS \\
$96-107.99$ & 93 & 120.79 & 6.54 & 67 & 121.79 & 4.75 & $<0.01$ \\
$108-119.99$ & 67 & 123.31 & 6.55 & 57 & 125.83 & 5.69 & $<0.001$ \\
$120-131.99$ & 54 & 130.13 & 6.16 & 86 & 132.24 & 9.69 & $<0.001$ \\
$<=132$ & 49 & 131.03 & 7.91 & 66 & 137.25 & 6.40 & $<0.001$ \\
\hline
\end{tabular}

NS- Not significant, $N$-Number of children 
Table 3. Prevalence of stunting of primary school children by age and settlement

\begin{tabular}{|c|c|c|c|c|c|}
\hline \multirow{2}{*}{$\begin{array}{l}\text { Age in } \\
\text { months }\end{array}$} & \multicolumn{2}{|c|}{ New Settlement } & \multicolumn{2}{|c|}{ Old Settlement } & \multirow{2}{*}{$\begin{array}{c}\chi^{2} \\
\text { (p-value) }\end{array}$} \\
\hline & $\mathbf{N}$ & $\begin{array}{c}\text { No Stunted } \\
(\%)\end{array}$ & $\mathbf{N}$ & $\begin{array}{c}\text { No Stunted } \\
(\%)\end{array}$ & \\
\hline \multicolumn{6}{|l|}{ Males } \\
\hline $60-71.99$ & 45 & $18(40.0)^{a}$ & - & - & 5.52 \\
\hline $72-83.99$ & 94 & $37(39.4)$ & 27 & $4(14.8)^{\mathrm{a}}$ & $(0.0188)$ \\
\hline $84-95.99$ & 85 & $28(32.9)$ & 62 & $9(14.5)$ & \\
\hline $96-107.99$ & 84 & $34(40.5)$ & 57 & $11(19.3)$ & \\
\hline 108.119 .99 & 76 & $24(31.6)$ & 60 & $16(26.7)$ & \\
\hline $120-131.99$ & 70 & $23(32.9)$ & 69 & $29(42.0)$ & \\
\hline$>=132$ & 54 & $20(37.0)$ & 98 & $39(39.8)$ & \\
\hline $\begin{array}{l}\text { All age } \\
\text { groups }\end{array}$ & 508 & $184(36.2)$ & 373 & $107(28.9)$ & \\
\hline \multicolumn{6}{|l|}{ Females } \\
\hline $60-71.99$ & 30 & $6(20)^{a}$ & - & - & 0.060 \\
\hline $72-83.99$ & 81 & $20(24.69)$ & 19 & $4(21.05)^{a}$ & $(0.4378)$ \\
\hline $84-95.99$ & 59 & $14(23.73)$ & 51 & $13(25.49)$ & \\
\hline $96-107.99$ & 93 & $22(23.65)$ & 67 & $8(11.94)$ & \\
\hline $108-119.99$ & 67 & $23(34.32)$ & 57 & $14(24.56)$ & \\
\hline $120-131.99$ & 54 & $22(40.74)$ & 86 & $26(30.23)$ & \\
\hline$<=132$ & 49 & $28(57.14)$ & 66 & $34(51.51)$ & \\
\hline $\begin{array}{l}\text { All age } \\
\text { group }\end{array}$ & 433 & $135(31.17)$ & 346 & $99(28.61)$ & \\
\hline
\end{tabular}

${ }^{*}$ Comparison of prevalence of stunting among children between new and old settlements

$N$ - Number of children 
Table 4. Prevalence of wasting of primary school children by age and settlement

\begin{tabular}{|c|c|c|c|c|c|}
\hline \multirow{2}{*}{$\begin{array}{l}\text { Age in } \\
\text { months }\end{array}$} & \multicolumn{2}{|c|}{ New Settlement } & \multicolumn{2}{|c|}{ Old Settlement } & \multirow{2}{*}{$\begin{array}{c}\chi^{2} \\
\text { (p-value) }\end{array}$} \\
\hline & $\mathbf{N}$ & $\begin{array}{c}\text { No Stunted } \\
(\%)\end{array}$ & $\mathbf{N}$ & $\begin{array}{c}\text { No Stunted } \\
(\%)\end{array}$ & \\
\hline \multicolumn{6}{|l|}{ Males } \\
\hline $60-71.99$ & 45 & $18(40.00)^{a}$ & - & - & 47.02 \\
\hline 72-83.99 & 94 & $47(50.00)$ & 27 & $8(29.63)^{a}$ & $(<0.0001)$ \\
\hline 84-95.99 & 85 & $50(58.82)$ & 62 & $26(41.94)$ & \\
\hline 96-107.99 & 84 & $44(52.38)$ & 57 & $14(24.56)$ & \\
\hline 108.119 .99 & 76 & $43(56.58)$ & 60 & $15(25.00)$ & \\
\hline $120-131.99$ & 70 & $34(48.57)$ & 69 & $16(23.19)$ & \\
\hline$>=132$ & 17 & $8(47.06)$ & 44 & $8(18.18)$ & \\
\hline $\begin{array}{l}\text { All age } \\
\text { groups }\end{array}$ & 471 & $244(51.80)$ & 319 & $87(27.27)$ & \\
\hline \multicolumn{6}{|l|}{ Females } \\
\hline $60-71.99$ & 30 & $23(76.67)^{a}$ & - & - & 32.08 \\
\hline 72-83.99 & 81 & $36(44.44)$ & 19 & $6(31.58)^{\mathrm{a}}$ & $(<0.0001)$ \\
\hline $84-95.99$ & 59 & $33(55.93)$ & 51 & $9(17.65)$ & \\
\hline 96-107.99 & 93 & $42(45.16)$ & 67 & $19(28.36)$ & \\
\hline $108-119.99$ & 67 & $25(37.31)$ & 57 & $11(19.30)$ & \\
\hline $120-131.99$ & - & - & 0 & - & \\
\hline$<=132$ & - & - & 0 & - & \\
\hline $\begin{array}{l}\text { All age } \\
\text { group }\end{array}$ & 330 & $159(48.18)$ & 194 & $45(23.20)$ & \\
\hline
\end{tabular}

${ }^{*}$ Comparison of prevalence of wasting among male children between new and old settlements $N$-Number of children 
Table 5. Prevalence of underweight of primary school children by age and settlement

\begin{tabular}{|c|c|c|c|c|c|}
\hline \multirow{2}{*}{$\begin{array}{l}\text { Age in } \\
\text { months }\end{array}$} & \multicolumn{2}{|c|}{ New Settlement } & \multicolumn{2}{|c|}{ Old Settlement } & \multirow{2}{*}{$\begin{array}{c}\chi^{2} \\
\text { (p-value) }\end{array}$} \\
\hline & $\mathbf{N}$ & $\begin{array}{c}\text { No Stunted } \\
(\%)\end{array}$ & $\mathbf{N}$ & $\begin{array}{c}\text { No Stunted } \\
(\%) \\
\end{array}$ & \\
\hline \multicolumn{6}{|l|}{ Males } \\
\hline $60-71.99$ & 45 & $28(62.22)^{a}$ & - & - & 27.43 \\
\hline $72-83.99$ & 94 & $69(73.40)$ & 27 & $12(44.44)^{a}$ & $(<0.0001)$ \\
\hline 84-95.99 & 85 & $39(45.88)$ & 62 & $27(43.54)$ & \\
\hline $96-107.99$ & 84 & $58(69.04)$ & 57 & $27(47.37)$ & \\
\hline 108.119 .99 & 76 & $54(71.05)$ & 60 & $22(36.66)$ & \\
\hline $120-131.99$ & 70 & $48(68.57)$ & 69 & $37(53.62)$ & \\
\hline$>=132$ & 54 & $36(66.66)$ & 98 & $53(54.08)$ & \\
\hline $\begin{array}{l}\text { All age } \\
\text { groups }\end{array}$ & 508 & $332(65.35)$ & 373 & $178(47.72)$ & \\
\hline \multicolumn{6}{|l|}{ Females } \\
\hline $60-71.99$ & 30 & $17(56.66)^{\mathrm{a}}$ & - & - & 51.78 \\
\hline $72-83.99$ & 81 & $45(55.55)$ & 19 & $8(42.10)^{a}$ & $(<0.0001)$ \\
\hline 84-95.99 & 59 & $41(69.49)$ & 51 & $12(23.53)$ & \\
\hline $96-107.99$ & 93 & $54(58.06)$ & 67 & $21(31.34)$ & \\
\hline $108-119.99$ & 67 & $37(55.22)$ & 57 & $20(35.08)$ & \\
\hline 120-131.99 & 54 & $39(72.22)$ & 86 & $36(41.86)$ & \\
\hline$<=132$ & 49 & $37(75.51)$ & 66 & $32(48.48)$ & \\
\hline $\begin{array}{l}\text { All age } \\
\text { group }\end{array}$ & 433 & $270(62.35)$ & 346 & $129(38.28)$ & \\
\hline
\end{tabular}

${ }^{*}$ Comparison of prevalence of wasting among male children between new and old settlements $N$-Number of children 
Table 6. Haemoglobin concentrations of primary school children by settlement

\begin{tabular}{|c|c|c|c|c|c|c|}
\hline \multirow{2}{*}{$\begin{array}{l}\text { Haemoglobin } \\
\text { concentrations } \\
(\mathrm{g} / \mathrm{dL})\end{array}$} & \multicolumn{2}{|c|}{ New Settlement } & \multicolumn{2}{|c|}{ Old Settlement } & \multicolumn{2}{|c|}{ Total } \\
\hline & $\mathbf{N}$ & $(\%)$ & $\mathbf{N}$ & $(\%)$ & $\mathbf{N}$ & $(\%)$ \\
\hline \multicolumn{7}{|l|}{ Males } \\
\hline $6.0-6.9$ & 4 & 0.83 & 2 & 1.00 & 6 & 0.87 \\
\hline 7.0-7.9 & 12 & 2.48 & 1 & 0.50 & 13 & 1.90 \\
\hline $8.0-8.9$ & 25 & 5.18 & 5 & 2.49 & 30 & 4.37 \\
\hline $9.0-9.9$ & 81 & 16.77 & 11 & 5.47 & 92 & 13.41 \\
\hline $10.0-10.9$ & 200 & 41.41 & 63 & 31.34 & 263 & 38.34 \\
\hline 11.0-11.9 & 126 & 26.09 & 60 & 29.85 & 186 & 27.11 \\
\hline $12.0-12.9$ & 33 & 6.83 & 46 & 22.89 & 79 & 11.51 \\
\hline $13.0-13.9$ & 2 & 0.41 & 8 & 3.98 & 10 & 1.46 \\
\hline $14.0-14.9$ & 0 & 0.00 & 3 & 1.49 & 3 & 0.44 \\
\hline $15.0-15.9$ & 0 & 0.00 & 2 & 1.00 & 2 & 0.29 \\
\hline Females & & . & & & & $\cdot$ \\
\hline $6.0-6.9$ & 4 & 0.94 & 0 & 0.00 & 4 & 0.67 \\
\hline $7.0-7.9$ & 5 & 1.18 & 0 & 0.00 & 5 & 0.84 \\
\hline $8.0-8.9$ & 15 & 3.53 & 4 & 2.38 & 19 & 3.20 \\
\hline $9.0-9.9$ & 79 & 18.59 & 8 & 4.76 & 87 & 14.67 \\
\hline $10.0-10.9$ & 194 & 45.65 & 58 & 34.52 & 252 & 42.50 \\
\hline $11.0-11.9$ & 86 & 20.24 & 55 & 32.74 & 141 & 23.78 \\
\hline $12.0-12.9$ & 39 & 9.18 & 36 & 21.43 & 75 & 12.65 \\
\hline 13.0-13.9 & 1 & 0.24 & 5 & 2.98 & 6 & 1.01 \\
\hline $14.0-14.9$ & 0 & 0.00 & 2 & 1.19 & 2 & 0.34 \\
\hline $15.0-15.9$ & 1 & 0.24 & 0 & 0.00 & 1 & 0.17 \\
\hline
\end{tabular}

$N$ - Number of children 
Figure 1. Distribution curves of height-for-age in relation to reference $Z$-scores (all age/sex groups)

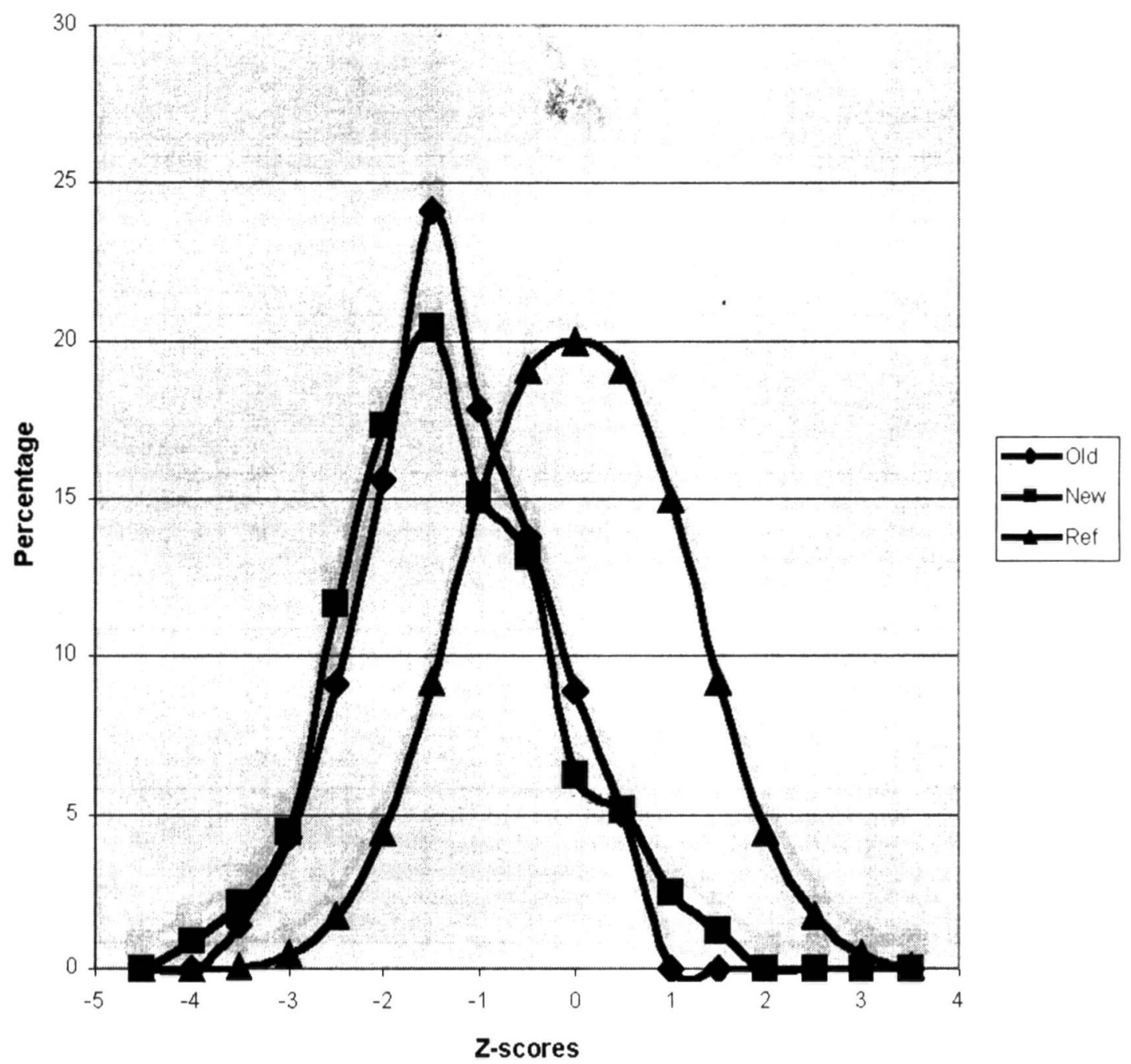

Old refers to old settlement

New refers to new settlement

Ref refers to reference population 
Figure 2. Distribution curves of weight-for-height in relation to reference Z-scores (all age/sex groups)

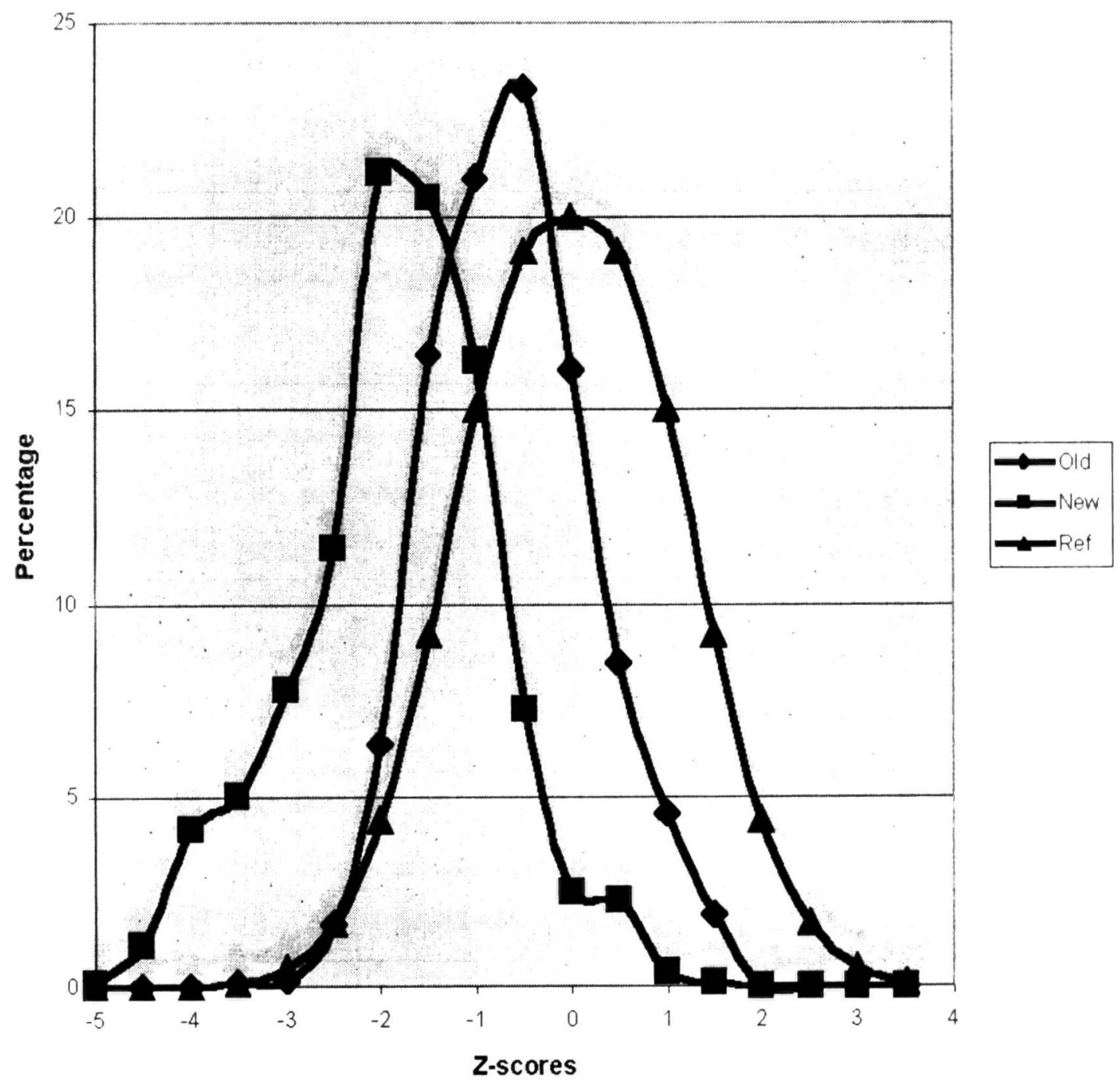

Old referes to old settlement

New referes to new settlement

Ref referes to reference population 